\title{
Pengaruh Komitmen Terhadap Kinerja Pegawai Negeri Sipil Di Kota Pekanbaru
}

\author{
Novita \\ Sekolah Tinggi Ilmu Ekonomi Riau \\ Jl. HR. Subrantas No 57 Pekanbaru 28293 \\ Email: nofa_com@yahoo.com
}

\begin{abstract}
Civil Servants are employees were seen from the financial establishment, as judged That this employee has a relatively high salary and plus allowances and health insurance, education and old age security. The issue of the performance of civil servants still in the spotlight, which, although he had done civil service reform, but at lower levels of service to the community still felt alone is not optimal. Some literature states that this is due to a lack of commitment to provide public services under the notabenenya no money and just a lot of complaining. This research was conducted in the Parliament Secretariat Pekanbaru City as a base for the people's voice, this study used a sample of 56 people with census methods, data were collected by questionnaire and analyzed using simple linear regression analysis. The study says that the commitment of a significant effect on the performance of employees. This proves that the employee committed in serving the community, the better the performance achieved in the country devoted to this.
\end{abstract}

Keywords: Employee Performance, Commitment

Sekretariat DPRD Kota Pekanbaru merupakan unsur pelayanan terhadap DPRD dipimpin oleh seorang Sekretaris DPRD yang secara teknis operasional berada di bawah dan bertanggung jawab kepada pimpinan DPRD sedangkan secara administrative bertanggungjawab kepada Walikota melalui Sekretariat Daerah. Sebagai dasar hukum pembentukan Sekretariat DPRD Kota Pekanbaru adalah berdasarkan: Peraturan Walikota Nomor 16 Tahun 2008 tentang Rincian Tugas, Fungsi dan Tata Kerja Sekretariat Daerah, Sekretariat DPRD, Kecamatan dan Kelurahan di lingkungan Pemerintah Kota Pekanbaru. Sekretaris DPRD dibantu oleh tiga orang kepala bagian, 6 orang kepada sub bagian dan seluruhnya berjumlah 56 orang pegawai. Untuk lebih jelasnya dapat dilihat pada gambar struktur organisasi Sekretariat DPRD Kota Pekanbaru.

Organisasi sekretariat DPRD adalah unit kerja pelayanan yang menjembatani eksekutif, legislatif serta masyarakat luas. Organisasi ini dalam mencapai tujuannya yang telah ditetapkan Kota Pekanbaru tidak terlepas dari peran sumber daya manusianya yaitu pegawainya. Pegawai pada sekretariat DPRD Kota Pekanbaru apabila dilihat dari pendidikan, golongan dan masa kerja sebagai penopang pelaksanaan tugas Sekretariat Dewan DPRD.

Pegawai yang memiliki komitmen kerja dalam melaksanakan tugasnya akan memberikan keberhasilan kepada pencapaian tugas lembaga. Begitu pula sebaliknya, pentingnya komitmen kerja bagi seorang pegawai dalam melaksanakan pekerjaan yang terkait kepada kesungguhan dalam melaksanakan pekerjaannya. Kesungguhan ini akan memberikan dampak pencapaian atau kinerja baik secara individu maupun secara kelembagaan. Rendahnya kualitas sumber daya manusia juga akan menjadi batu sandungan dalam era globalisasi, dimana era globalisasi merupakan era persaingan mutu. Jika bangsa Indonesia ingin berkiprah dalam percaturan global, maka langkah pertama yang harus dilakukan adalah menata sumber daya manusia, baik dari aspek intelektual, spiritual, kreativitas, moral, maupun tanggung jawab. 
Pegawai adalah manusia yang mempunyai sifat kemanusiaan, perasaan dan kebutuhan yang beraneka ragam. Kebutuhan ini bersifat fisik maupun non fisik yang harus dipenuhi agar dapat hidup secara layak dan manusiawi. Hal ini menyebabkan timbulnya suatu pendekatan yang berdasarkan pada kesejahteraan pegawai dalam manajemen personalia. Pegawai harus mendapatkan perlakuan sedemikian rupa sehingga kerjasama antara pimpinan dan bawahan dapat terjalin dengan baik. Komunikasi yang baik diperlukan dalam rangka menjalin hubungan antara atasan dengan bawahan untuk keberhasilan suatu organisasi dalam mencapai tujuan yang telah ditetapkan. Kondisi ini dinilai penting dan memberikan kontribusi positif.

Sebagai manusia, pegawai juga mempunyai tujuan sehingga diperlukan suatu integrasi antara tujuan organisasi dengan tujuan pegawai. Untuk mengusahakan integrasi antara tujuan organisasi dan tujuan pegawai, perlu diketahui apa yang menjadi kebutuhan masing-masing pihak. Kebutuhan pegawai diusahakan dapat terpenuhi melalui pekerjaannya. Apabila seorang pegawai sudah terpenuhi segala kebutuhannya maka dia akan mencapai kepuasan kerja dan memiliki komitmen terhadap organisasi. Tingginya komitmen pegawai dapat mempengaruhi usaha suatu organisasi secara positif. Adanya komitmen akan membuat pegawai mendukung semua kegiatan organisasi secara aktif, ini berarti pegawai akan bekerja lebih produktif.

Berdasarkan fenomena yang ada berkaitan dengan kinerja pegawai ditemui gejala-gejala sebagai berikut : $70 \%$ kegiatan perjalanan dinas keluar kota diberikan kepada pegawai yang sama, hal ini menunjukkan adanya kecenderungan persaingan yang tidak sehat, sehingga cenderung untuk saling memperebutkan dan juga menyebabkan pegawai kurang kompak dalam bekerja dengan kurangnya kerjasama antar pegawai dalam menyelesaikan sebuah pekerjaan yang menjadi tanggung jawab organisasi. Pegawai golongan III yang tidak memiliki jabatan (20\%) padahal memenuhi syarat pangkat dan golongannya serta masalah ada sebagian pegawai yang bekerja dengan intensitas kerja yang padat sedangkan sebagian lainnya tidak ada sesibuk pegawai tersebut.

Pegawai yang dalam memegang jabatan tidak sesuai (35\%) dengan pendidikan yang diperolehnya, sehingga pegawai tersebut merasa kurang mampu untuk mengaktualisasikan dirinya dalam bekerja. Pegawai cenderung kurang peduli (30\%) dengan pekerjaan yang menjadi tanggung jawabnya dan lebih mengutamakan kepentingan pribadinya atau keluarganya seperti menjemput anak dan mengantar ke sekolah, belanja dan lainnya.

Kondisi ini mengindikasikan rendahnya kinerja pegawai dalam memberikan pelayanan kepada masyarakat. Menurut hasil penelitian sebelumnya seperti: Sudiro (2008) hasil penelitiannya menunjukkan bahwa masing-masing variabel berhubungan dan berpengaruh berdasarkan koefisien terstandarisasi menunjukkan pengaruh timbal balik secara positif dan signifikan antara kepuasan keluarga dan kepuasan kerja. Pengaruh timbal balik antara kepuasan kerja dan komitmen kerja juga positif dan signifikan. Di samping itu, hasil penelitian ini juga menunjukkan koefisien terstandardisasi untuk pengaruh antara kepuasan kerja terhadap prestasi kerja, komitmen kerja terhadap prestasi kerja dan prestasi kerja terhadap karir dosen semuanya mempunyai pengaruh positif dan signifikan.

Kemudian diperkuat oleh penelitian Supriyono (2006) berdasarkan hasil penelitian disimpulkan bahwa komitmen organisasi dan partisipasi penganggaran merupakan variabel perantara parsial pengaruh usia terhadap kinerja manajer. Usia, komitmen organisasi dan partisipasi penganggaran secara bersama-sama mempunyai pengaruh positif dan secara statistika signifikan terhadap kinerja manajer. Juga Cahyasumirat (2006) menjelaskan bahwa profesionalisme secara positif berpengaruh terhadap kepuasan kerja internal auditor namun tidak memiliki 
pengaruh positif terhadap kinerja. Sedangkan komitmen organisasi tidak berpengaruh terhadap kinerja dan kepuasan kerja.

Hasil penelitian tersebut menjelaskan bahwa kinerja pegawai dipengaruhi oleh banyak faktor diantaranya adalah faktor komitmen. Menurut Mathis dan Jackson dalam Sopiah (2008: 155) komitmen adalah derajat yang mana karyawan percaya dan menerima tujuan-tujuan organisasi dan akan tetap tinggal atau tidak akan meninggalkan organisasi. Kemudian Mowday dalam Sopiah (2008: 156 - 157) menyebut komitmen kerja pegawai sebagai istilah lain dari komitmen organisasional menurutnya, komitmen merupakan dimensi perilaku penting yang dapat digunakan untuk menilai kecenderungan karyawan untuk bertahan sebagai anggota organisasi. Komitmen merupakan identifikasi dan keterlibatan seseorang yang relatif kuat terhadap organisasi. Komitmen adalah keinginan anggota organisasi untuk tetap mempertahankan keanggotaannya dalam organisasi dan bersedia berusaha keras bagi pencapaian tujuan organisasi.

Selain itu juga Bashaw dan Grant dalam Sopiah (2008: 156) menyatakan komitmen mencakup kebanggaan anggota, kesetiaan anggota dan kemauan anggota pada organisasi. Kemudian Knoop dalam Sopiah (2008: 156) menyebutkan komitmen sebagai keberpihakan dan loyalitas karyawan terhadap organisasi dan tujuan organisasi. Robbin dalam Sopiah (2008: 156) mendefinisikan komitmen pegawai sebagai suatu sikap yang merefleksikan perasaan suka atau tidak suka dari karyawan terhadap organisasi. O'Reilly dalam Sopiah (2008: 156) menyebutkan komitmen pegawai pada organisasi sebagai ikatan kejiwaan individu terhadap organisasi yang mencakup keterlibatan kerja, kesetiaan dan perasaan percaya terhadap nilai-nilai organisasi.

Steer dan Porter dalam Sopiah (2008: 156) menyatakan bahwa suatu bentuk komitmen yang muncul bukan hanya bersifat loyalitas yang pasif, tetapi juga melibatkan hubungan yang aktif dengan organisasi kerja yang memiliki tujuan memberikan segala usaha demi keberhasilan organisasi yang bersangkutan. Timpe dalam Pangabean (2001:137) menyatakan bahwa komitmen adalah mematuhi segala sesuatu kesepakatan yang telah dibuat (kedisiplinan) tanpa dilanggar. Konsep ini diartikan bahwa komitrnen merupakan kedisiplinan seorang pegawai terhadap peraturan-peraturan di dalam organisasi yang telah disepakati bersama.

Dalam kehidupan sehari-hari komitmen sering diartikan sebagai suatu kesepakatan. Mengenai hal ini Gibson dalam Pangabean (2001:137) mengemukakan bahwa komitmen adalah rasa identifikasi dan loyalitas atau kesetiaan yang dinyatakan oleh seorang pegawai terhadap organisasi. Komitmen memberikan rasa tanggung jawab terhadap pekerjaan yang dilakukan seseorang. Menurut Robbins (2003: 92), "Komitmen pegawai didefinisikan sebagai suatu keadaan dimana seorang pegawai memihak pada suatu organisasi tertentu dan tujuantujuannya serta berniat memelihara keanggotaan dalam organisasi itu". Komitmen pada organisasi yang tinggi dapat diartikan bahwa pemihakan pegawai (loyalitas) pada organisasi yang memperkerjakannya adalah tinggi.

Dari pendapat di atas, dapat disimpulkan bahwa komitmen pegawai adalah sebagai suatu keadaan dimana seorang pegawai memihak pada suatu organisasi tertentu dan tujuan-tujuannya serta berniat memelihara keanggotaan dalam organisasi itu. Pengukuran komitmen menurut Sopiah (2008: 157) menyatakan komitmen pegawai merupakan suatu ikatan psikologis karyawan pada organisasi yang ditandai: (1) kepercayaan dan penerimaan yang kuat atas tujuan dan nilai-nilai organisasi, (2) kemauan untuk mengusahakan pencapaian kepentingan organisasi, dan (3) keinginan yang kuat untuk mempertahankan keanggotaan organisasi.

Luthans (2005:252) menyatakan bahwa komitmen pegawai mengacu pada loyalitas pegawai pada organisasi dan 
ditentukan oleh sejumlah variabel orang, organisasi, dan non organisasi. Komitmen secara umum mempunyai tiga komponen: (afektif) pendekatan emosi, berkelanjutan (biaya meninggalkan organisasi) dan normatif (kewajiban untuk bertahan).

Lebih lanjut Luthans (2005:249) menyatakan bahwa sebagai sikap, komitmen pegawai paling sering didefinisikan sebagai: (1) keinginan kuat untuk tetap sebagai anggota organisasi tertentu, (2) keinginan untuk berusaha keras sesuai keinginan organisasi dan (3) keyakinan tertentu dan penerimaan nilai dan tujuan organisasi. Setiap pegawai memiliki dasar dan tingkah laku yang berbeda berdasarkan komitmen organisasi yang dimilikinya. Pegawai yang memiliki komitmen organisasi dengan dasar afektif memiliki tingkah laku berbeda dengan pegawai yang berdasarkan continuance. Pegawai yang ingin menjadi anggota akan memiliki keinginan untuk menggunakan usaha yang sesuai dengan tujuan organisasi. Sebaliknya, mereka yang terpaksa menjadi anggota akan menghindari kerugian finansial dan kerugian lain, sehingga mungkin hanya melakukan usaha yang tidak maksimal. Sementara itu, komponen normatif yang berkembang sebagai hasil dari pengalaman sosialisasi, tergantung dari sejauh apa perasaan kewajiban yang dimiliki pegawai. Komponen normatif menimbulkan perasaan kewajiban pada pegawai untuk memberi balasan atas apa yang telah diterimanya dari organisasi.

Pada dasarnya setiap orang mempunyai komitmen dalam melaksanakan suatu pekerjaan, namun ada yang memiliki komitmen yang tinggi terhadap pekerjaan dan ada pula yang rendah. Tinggi rendahnya komitmen dipengaruhi oleh tingkat perkembangan dan proses kejiwaan seseorang. Israil dalam Pangabean (2001:137) menyatakan bahwa komitmen seseorang itu dapat bertambah atau berkurang terhadap pekerjaannya, dan sangat dipengaruhi oleh sikap. Sikap positif terhadap pekerjaan akan membuat seseorang senang bekerja. Jika seseorang memiliki komitmen yang tinggi terhadap pekerjaan maupun organisasinya, maka pencapaian tujuan yang diharapkan akan lebih efektif dan efisien. Sebaliknya jika komitmen kerja seorang pegawai rendah, maka akan menghambat kelancaran pencapaian tujuan organisasi.

Pegawai yang mempunyai komitmen tinggi terhadap pekerjaannya akan bersemangat, berdisiplin tinggi dan sekaligus berkesempatan untuk meningkatkan profesionalisme dan produktivitas kerja. Komitmen kerja yang tinggi juga memungkinkan bagi pegawai untuk bekerja keras menghadapi tantangan dan hambatan. Komitmen juga menjadikan sasaran pegawai dan sasaran organisasi menjadi satu dan sejalan. Seorang pegawai yang betul-betul berpegang pada komitmen bersedia melakukan pengorbanan. Dengan kata lain pegawai yang berkomitmen tinggi adalah patriot organisasi dan pengobar semangat yang alami.

Penelitian ini ingin membuktikan apakah komitmen pegawai merupakan faktor yang mempengaruhi kinerja pegawai dalam memberikan pelayanan kepada masyarakat di secretariat DPRD kota Pekanbaru.

\section{METODE}

Penelitian ini menggunakan pendekatan survey, yang dilakukan kepada seluruh pegawai di lingkungan secretariat DPRD kota Pekanbaru dengan responden berjumlah 56 orang dan dianalisis dengan menggunakan regresi linier sederhana berganda.

\section{HASIL}

Kinerja pegawai adalah suatu kumpulan total dari perilaku kerja yang ada pada pekerja, dalam kaitannya dengan kinerja pegawai yaitu perilaku kerja pegawai. Dimensi kinerja pegawai antara lain: kualitas (yang meliputi: akurasi, ketelitian, penampilan dan penrimaan keluaran). Kemudian kuantitas (yang meliputi: volume keluaran dan kontribusi), selain itu supervisi yang diperlukan (yang meliputi: (membutuhkan saran, arahan dan 
perbaikan) dan kehadiran (yang meliputi: regularitas, dapat dipercayai/diandalkan dan ketepatan waktu) serta konservasi (yang meliputi: pencegahan pemborosan, kerusakan dan pemeliharaan peralatan).

Data hasil penelitian tentang variabel kinerja pegawai Sekretariat DPRD Kota Pekanbaru dapat dilihat bahwa skor yang diperoleh dari hasil perhitungan mencapai 3,75 ini menunjukkan bahwa kinerja pegawai dalam kategori sedang. Kemudian dari hasil perhitungan variabel komitmen pegawai bahwa dengan skor 3.17 lebih rendah dibandingkan dengan kinerja yang juga menunjukkan kondisi komitmen pegawai sedang.

Dari hasil perhitungan regresi sederhana dengan menggunakan program SPSS versi 18 diperoleh perhitungan sebagai berikut:

Model Summary

\begin{tabular}{|l|r|r|r|r|}
\hline Model & $\mathrm{R}$ & $\begin{array}{c}\mathrm{R} \\
\text { Square }\end{array}$ & $\begin{array}{c}\text { Adjusted R } \\
\text { Square }\end{array}$ & $\begin{array}{c}\text { Std. Error of } \\
\text { the Estimate }\end{array}$ \\
\hline 1 & $.777^{\mathrm{a}}$ & .604 & .597 & 3.76989 \\
\hline
\end{tabular}

a. Predictors: (Constant),

Komitmen

Dari data model summary tersebut dilihat bahwa nilai $\mathrm{R}$ square sebesar 0,604 angka ini merupakan decimal dengan persentase $(0,604$ $x$ 100) menjadi $60,4 \%$. Ini menunjukkan bahwa kontribusi komitmen pegawai terhadap kinerja pegawai sebesar $60,4 \%$ dan angka ini relatif besar dalam membuat kinerja pegawai ke depannya semakin baik. Kemudian juga dapat dilihat nilai uji signifikansi variabel komitmen terhadap kinerja pegawai sebagai berikut:

Coefficients $^{\mathrm{a}}$

\begin{tabular}{|c|c|c|c|c|c|}
\hline \multirow[b]{2}{*}{ Model } & \multicolumn{2}{|c|}{$\begin{array}{l}\text { Unstandardized } \\
\text { Coefficients }\end{array}$} & \multirow{2}{*}{$\begin{array}{c}\begin{array}{c}\text { Standardized } \\
\text { Coefficients }\end{array} \\
\text { Beta }\end{array}$} & \multirow[b]{2}{*}{$\mathrm{t}$} & \multirow[b]{2}{*}{ Sig. } \\
\hline & B & $\begin{array}{l}\text { Std. } \\
\text { Error }\end{array}$ & & & \\
\hline 1 (Constant) & 48.708 & 2.524 & & 19.295 & .000 \\
\hline Komitmen & .339 & .037 & .777 & 9.084 & .000 \\
\hline
\end{tabular}

a. Dependent Variable: Kinerja

Data pada tatebl coefficients menjelaskan bahwa dengan nilai t hitungan 9,084 dan dibandingkan dengan nilai $\mathrm{t}$ tabel dengan $\mathrm{n}=56$ dan alpha 5\% maka nilai $\mathrm{t}$ tabel sebesar 2,003 atau nilai sig. sebesar 0,000 lebih kecil dari 0,05. Angka tersebut menunjukkan bahwa: $\mathrm{t}$ hitung $>\mathrm{t}$ tabel maka Ho ditolak dan hipotesis penelitian diterima. Ini membuktikan bahwa komitmen berpengaruh signifikan terhadap kinerja pegawai. Kemudian juga dapat dilihat nilai B seebsar 0,339 yang memiliki arti bahwa komitmen memberikan pengaruh positif terhadap kinerja pegawai, bahwa semakin tinggi komitmen pegawai maka kinerjanya juga dalam melayani masyarakat akan semakin baik pula.

\section{PEMBAHASAN}

Komitmen berpengaruh signifikan terhadap kinerja pegawai Sekretariat DPRD Kota Pekanbaru". Dari hasil pengolahan data diketahui besarnya pengaruh komitmen (X) yang secara langsung mempengaruhi kinerja (Y) dinyatakan dengan koefisien sebesar 0,339. Ini menunjukkan bahwa komitmen tidak begitu mempengaruhi kinerja pegawai. Komitmen adalah sebagai suatu keadaan dimana seorang pegawai memihak pada suatu organisasi tertentu dan tujuan-tujuannya serta berniat memelihara keanggotaan dalam organisasi itu. Seorang pegawai yang memiliki kepercayaan dan penerimaan yang kuat atas tujuan dan nilainilai organisasi. Kemudian kemauan untuk mengusahakan tercapainya kepentingan organisasi selain itu keinginan yang kuat untuk mempertahankan kedudukan sebagai anggota organisasi dan kesetiaan karyawan pada organisasi serta kebanggan karyawan pada organisasi akan meningkat dalam bekerja.

Hasil penelitian ini sejalan dengan apa yang disampaikan oleh Sudiro (2008) hasil penelitiannya menunjukkan bahwa masing-masing variabel berhubungan dan berpengaruh berdasarkan koefisien terstandarisasi menunjukkan pengaruh timbal balik secara positif dan signifikan antara kepuasan keluarga dan kepuasan kerja. Pengaruh timbal balik antara kepuasan kerja dan komitmen kerja juga 
positif dan signifikan. Di samping itu, hasil penelitian ini juga menunjukkan koefisien terstandardisasi untuk pengaruh antara kepuasan kerja terhadap prestasi kerja, komitmen kerja terhadap prestasi kerja dan prestasi kerja terhadap karir dosen semuanya mempunyai pengaruh positif dan signifikan.

Supriyono (2006) berdasarkan hasil penelitian disimpulkan bahwa komitmen organisasi dan partisipasi penganggaran merupakan variabel perantara parsial pengaruh usia terhadap kinerja manajer. Usia, komitmen organisasi dan partisipasi penganggaran secara bersama-sama mempunyai pengaruh positif dan secara statistika signifikan terhadap kinerja manajer. Cahyasumirat (2006) hasil penelitiannya menunjukkan bahwa profesionalisme secara positif berpengaruh terhadap kepuasan kerja internal auditor namun tidak memiliki pengaruh positif terhadap kinerja. Sedangkan komitmen organisasi tidak berpengaruh terhadap kinerja dan kepuasan kerja.

Sekretariat DPRD mempunyai fungsi vital dalam penyelenggaraan kegiatan DPRD. Dari hasil penelitian diketahui kebersamaan merupakan faktor dominan yang mempengaruhi kinerja. Dengan demikian, dalam bekerja, kebersamaan menjadi hal yang mutlak dengan maksud membangun sama rasa dalam bekerja sehingga pada akhirnya dapat meningkatkan kinerja pegawai. Apabila dilihat tempat pegawai bekerja yaitu Sekretariat DPRD, adanya kecenderungan bahwa pendapatan mempengaruhi komitmen pegawai dalam bekerja. Dimana apabila pendapatan menurun, maka komitmen pegawai dalam bekerja juga akan menurun.

\section{SIMPULAN}

Kesimpulan yang dapat diambil dalam penelitian ini menunjukkan bahwa komitmen berpengaruh signifikan terhadap kinerja pegawai. Ini membuktikan bahwa semakin komit pegawai dalam melayani masyarakat maka akan semakin baik kinerja yang dicapai dalam mengabdikan diri kepada Negara ini.

\section{DAFTAR RUJUKAN}

Cahyasumirat, Gunawan, 2006, Pengaruh profesionalisme dan komitmen organisasi terhadap kinerja internal auditor, dengan kepuasan kerja sebagai variabel intervening, Tesis, Universitas Diponegoro, Semarang.

Luthans, 2005, Work Volvos and Commitment International, Journal Manpower, Vol 17.3.

Pangabean, Mutiara, Sibarani, 2001, Manajemen Sumber Daya Manusia, Ghalia Indonesia, Bogor.

Sopiah, 2008, Perilaku Organisasional, Andi, Yogyakarta.

Sudiro, Ahmad, 2008, Pengaruh timbal balik antara kepuasan kerja dengan kepuasan keluarga dan komitmen kerja serta dampaknya terhadap prestasi kerja dan karir dosen, Jurnal manajemen dan kewirausahaanm, Vol. 10 Nomor 1, Maret 2008.

Supriyono, 2006, Pengaruh variabel perantara komitmen organisasi dan partisipasi penganggaran terhadap hubungan antara usia dan kinerja manajer di Indonesia, Jurnal ekonomi dan bisnis, Vol 6 Nomor 1 Februari 2006.

Peraturan Walikota Nomor 16 Tahun 2008 tentang Rincian Tugas, Fungsi dan Tata Kerja Sekretariat Daerah 